\title{
THE INSTITUTE OF STATUTORY LIMITATION INCRIMINAL PROCEDURE AND IN CRIMINAL LAW
}

\section{Elda Maloku}

${ }^{1}$ Department of Criminal Law, Iliria University, Kosovo

E-mail:malokuelda@gmail.com

ORCID: http://orcid.org/0000-0001-8856-2005

A RT ICLE INF O
Article history:
Received date 07.09 .2021
Accepted date 19.10 .2021
Published date 29.10 .2021
Section:
Law
D O I

$10.21303 / 2313-8416.2021 .002162$

KEYWORDS

Statutory Limitation

execution of punishment

tolling of Statutory Limitation

Absolute Statutory Limitation
A B S T RACT

The institute of statutory limitation in criminal procedure has an extreme importance and through this research we will get to know more about the new provisions of Criminal Procedure Code and the Criminal Code of Republic of Kosovo regarding the statute of limitations of the criminal prosecution and the statute of limitations of the execution of the criminal-legal sanctions.

The object of research: Analysis and the synthesis facts and essential legal provisions of Criminal Procedure and the Criminal Code of the Republic of Kosovo for statutory limitation (hereinafter SoL), by using scientific theory, methodology and scientific research in order to gain scientific knowledge.

The main scientific results: The institute of statutory limitation in the Criminal Procedure in the Republic of Kosovo is analyzed with the provisions of the Criminal Code and Criminal Procedure Code. Moreover, SoL is analyzed and compared with legal provisions in the abolished Criminal Code and the new Criminal Code of Republic of Kosovo as well. Improvement of the efficiency of the Institute of SoL in criminal law and criminal procedure has been found through new amendments to the legal provisions of the Code of Criminal Procedure and the Criminal Code

The area of practical use of the research results: Are the newest data for the institute of SoL in the criminal procedure and in criminal law as well. The conducted research made it possible for lawyers, criminologists, victimologists, Non-Governmental Organizations (hereafter: NGOs) and all stakeholders to obtain additional information about the Institute of SoL in Criminal Procedure Law and Criminal Law in the Republic of Kosovo.

Innovative technological product: Identification and the analysis of new changes in legal provisions of Criminal Procedure Code and Criminal Code of the Republic of Kosovo for efficiency improvement of SoL institute.

Scope of the innovative technological product: This research will contribute and fulfill the scientific knowledge fund on the SoL problem in Kosovo and its enforcement. Also, the research results can create some starting points for more complex scientific research in the future for the Institute of SoL in the Republic of Kosovo or in the other countries of the region.

(C) The Author(s) 2021. This is an open access article under the Creative Commons CC BY license

\section{Introduction}

Statute of Limitation is a very important legal institution which somehow fades the right of state authority to seek after criminal procedure on a perpetrator, because of the time expiration. However, they are considered as pragmatic devices to save courts and spare citizens from having to defend when memories have faded; witnesses are unavailable by death and disappearance and evidence is lost [1].

However, one of the questions that may interest the citizens, regardless of whether they have committed any criminal offense, or if they have been injured by any criminal offense, is the moment when they as individuals can start the criminal procedure, i.e., until which moment the execution of the final judgment can be requested. Therefore, committing a criminal offense, i.e., its proceeding and execution of the sentence, should be placed at a certain interval, otherwise, the punishment loses its purpose and due to the appearance of SoL, the imposed sentence has not been served/executed, and i.e., the persons (perpetrators of criminal offenses) have not been processed.

Most of the times when a person commits a criminal offense, the competent bodies immediately undertake the criminal prosecution and criminal proceedings are placed against the perpe- 
trator and a criminal sanction is imposed on that person. But, in some of the cases, the perpetrator cannot be identified. Also, it can happen because the perpetrator has escaped. In addition, it is possible that the perpetrator will be punished, but after the imposition of the sentence there can be real or legal obstacles which makes it impossible for the sentence to be executed [2]. Such obstacles can happen when the convict becomes seriously ill or escapes after sentencing. Also, there is a possibility for the convict to escape from the penitentiary institution where he or she was serving his or her sentence.

The legislation of the Republic of Kosovo, since the Provisional Criminal Code of Kosovo [3], Criminal Code of the Republic of Kosovo [4] as well as new amendments to the Provisions of Criminal Code of the Republic of Kosovo, have provided the SoL of criminal offences in Chapter X, article 99, 100, 101, 102, 103 and 104 [5].

\section{1. The object of research}

The object of this research is the institute of SoL based on the provisions of the Criminal Procedure Code and the Criminal Code of the Republic of Kosovo.

\section{2. Problem description}

The huge number of cases that were reached by SoL after war in Kosovo, both in terms of criminal prosecution and in terms of executions of the penal-legal sanctions has caused some perpetrators to avoid criminal-legal sanctions. This phenomenon aroused the increased interest of lawyers, criminologists, victimologists, sociologists, etc., thus many researches, projects, scientific works appeared. However, the authors were tried to analyze and to give specific recommendations on how to overcome and solve this problem that has emerged in Kosovo.

Also, it should not be forgotten the great help of the Institutes and NGO-s which through court hearings monitoring, published different reports in the national level for the SoL of criminal offences.

\section{3. Suggested solution to the problem}

There are many papers of Kosovars scholars dedicated to this problem, such as the author of many scientific papers and university textbooks in the criminal field, Professor Salihu [2, 6] in his book "Criminal Law general part" has elaborated and analyzed extremely well the institute of SoL. In chapter XI he starts from the notion and importance of SoL, SoL on criminal persecution and the interruption and tolling of SoL of criminal prosecution, SoL on executions of sanction, SoL for the execution of accessory punishments and measures of mandatory treatment and concludes by elaborating on the non-applicability of SoL of the criminal offenses of genocide and war crimes under international criminal law and under national law as well.

The author Hajdari regarding to the Institute of SoL on criminal persecution has given a major contribution, in his books such as "The right to Criminal Procedure" [7] also The Commentary Code of Criminal Procedure [8], where through his writings he offers suggested solutions to the challenges and problem of the Institute of SoL in Kosovo. The judge and professor of criminal field, Shala in his book "Introduction to Criminal Law"[9], elaborates extremely well the Institute of SoL in Chapter IX the penalty measurements and the SoL. Within this chapter he elaborates the general reviews for SoL, SoL on criminal persecution, SoL on executions of sanction, SoL for the execution of accessory punishments and measures of mandatory treatment.

Anyhow, through scientific works it has been proven that the rise of crime also raises the fear of violence and criminality [10], therefore new changes of legal provisions regarding the Institute of SoL, investigators trainings, prosecutors, judges and the positive influence of the media and NGOs in monitoring trials has led to the return of security toward citizens and at the same time reducing the fear of crime. Also, organized crime cannot be fought without an international police cooperation [11]. In the fight against prevention of organized crime, the amendment of the legal provisions of the new Criminal Code also helps us.

For a better combating and prevention of organized crime, the amendments of the new Criminal Code of the Republic of Kosovo seem to be very helpful regarding to SoL, as well as the bilateral and multilateral agreements regarding regional and international cooperation in the field of combating and preventing criminality. 
Moreover, an extremely huge contribution has been given by the research reports of the institutes and NGOs. So, the executive director of Kosovo Law Institute (KLI) in the report "General crimes in Kosovo, law vs. practice" [12] said that the analytic report is a result of systematic research and monitoring of cases in General Departments - Penal Division of all District Courts in the whole territory of Kosovo including its branches. KLI through this time has monitored in total 2,694 sessions where 2.015 were criminal cases. "Among the biggest problems in this department tend to be the SoL of cases" has said Miftaraj [13]. The researcher Thaqi emphasizes the fact that KLI has offered a lot of recommendations in order to address problems that were identified during monitoring of cases. Among other things, he recommended the Judicial Council of Kosovo and Prosecutorial Council of Kosovo to re-analyze the regulations on orientation norms, in order to create accurate indicators on measuring the efficiency of each judge and prosecutor, while for these institutions was recommended to increase accountability to judges and prosecutors who do not comply with legal deadlines in dealing with serious crime cases [13].

The aim of research is the analysis of facts and legal provisions of the Criminal Procedure Code and Criminal Code of the Republic of Kosovo for SoL institution.

Moreover, through this study it'll be analyzed the amendments of Provisional Criminal Code which entered into force on April 6, 2004, the Criminal Code of the Republic of Kosovo which entered into force on January 1, 2013, and the Criminal Code of the Republic of Kosovo which entered into force on April 14, 2019.

\section{Materials and methods}

Because of the complexity of the research, several methods have been implemented in order to support each other in problem solving. From special scientific methods in research, the method of analysis and synthesis will be used, which will be especially useful in researching the theoretical stands of domestic and foreign authors studying the criminal field, especially in the aspect of the SoL institution analysis. In similar circumstances, the method of induction and deduction will also be used. The research will also use the Comparative Method where it will be used mainly to compare different segments of research work.

\section{Research results and discussion}

\section{1. Notion and legal nature of SoL}

The SoL is a legal-material institution which leads to the loss of the right of state authorities to conduct criminal proceedings, to impose and enforce a criminal sanction against perpetrators of a criminal offense, due to the expiration of a certain period of time from committing a criminal offense.

With the appearance of the statute of limitations, the state loses the right to criminal prosecution and criminal sanctions that were imposed and must accept the force of time. Certain authors represent the view that SoL is a mixed material-processor institute, because from one hand are based on the right to punishment but on the other hand, it is also presented as a procedural obstacle for criminal prosecution.

In every phase of the criminal procedure, the court and other prosecuting authorities, as well as the bodies for the execution of criminal sanctions, are obliged that regarding to legal authorities, take care of, consider and enforce the statute of limitations.

As it is possible to see, the lawmaker has described two forms of SoL: SoL of criminal prosecution, which disables the procedure against the perpetrator of the criminal offense; as well as the SoL of the execution of the sentence.

\section{2. Statutory Limitation of criminal prosecution}

Over the determined time, from the commission of a criminal offense defined by law as a statute of limitations, no criminal prosecution can be instituted against the perpetrator, and if it is undertaken within the deadline determined by law, it does not lead to a final court decision, thus the procedure against the perpetrator will be terminated [14, p. 1068].

Criminal procedure can no longer be initiated against the perpetrator of the criminal offense, more precisely, it cannot be extended after the expiration of the term determined by law. Therefore, two situations are possible: 
- the first one is that if the criminal procedure is not yet initiated, upon the appearance of the SoL, the criminal prosecution ceases as the right of the competent body (police and prosecution) to initiate the procedure;

- the second one is that when the SoL occurs during the criminal procedure then the court terminates the proceedings.

In both cases, the legal consequence is the same - the competent body takes the ruling based on which the indictment is rejected due to the statute of limitations, as one of the reasons that permanently excludes criminal prosecution. According to article 82, the paragraph 1.2 of Criminal Procedure Code of the Republic of Kosovo, the state Prosecutor with a ruling dismisses the criminal report accepted by the police, or other sources within (30) days, if it is clear from the report that: the statute of limitations for criminal prosecution has expired [15]. Also, according to article 158, paragraph 1 and sub-paragraph 1.3 of this Code, the state Prosecutor terminates the investigation whenever it has been established by the evidence gathered that: the SoL has expired [16]. Article 250, paragraph 1 and sub-paragraph 1.3 of the above-mentioned Code gives the right to the defendant to file a motion to dismiss the indictment before the second hearing, where the defendant may file a motion to dismiss the indictment, based on these reasons: the statute of limitations for the criminal offense has expired, the offense is involved in pardon or there are other circumstances which impede prosecution [16]. While, according to the article 363, paragraph 1 and sub-paragraph 1.3. on the same Code, the competent court may issue a rejection judgment when the statutory limitation has expired and the offense is included in pardon, or when there are other circumstances that preclude prosecution [17].

Limitation periods are varied and how long this period will be, depend on the type and extent of punishment provided for the particular criminal offense. The SoL periods on criminal prosecution are provided in Criminal Code of the Republic of Kosovo. In the legal provision of article 99, paragraph 1, it's provided unless expressly provided otherwise by the Criminal Code, criminal prosecution may not be instituted if the following deadlines have elapsed:

1. Thirty (30) years from the commission of a criminal offense punishable by life long imprisonment.

2. Twenty (20) years from the commission of a criminal offense punishable by imprisonment of more than ten (10) years.

3. Fifteen (15) years from the commission of a criminal offense punishable by imprisonment of more than five (5) years.

4. Ten (10) years from the commission of a criminal offense punishable by imprisonment of more than three (3) years.

5. Six (6) years from the commission of a criminal offense punishable by imprisonment of more than one (1) year.

6. Four (4) years from the commission of a criminal offense punishable by imprisonment up to one (1) year or punishment of a fine [18].

So, as it can be seen above, depending on the sentence provided for the offense, the minimum period statute of limitations for criminal prosecution is 4 years (while on the Criminal Code 2012, the minimum period of the SoL was 2 years), whereas the maximum 30 years. When the law provides for more than one punishment for a criminal offense, the period of limitation shall be determined according to the most serious punishment [19].

The prosecution on SoL commences on the day when the criminal offence happened. Many Criminal Codes accept the theory of action and not of consequence. According to Criminal Code of the Republic of Kosovo, the commencement of SoL derives from the day the criminal offense was committed. If any consequence that constitutes an element of the offense appears later, then under Article 100, paragraph 1, the limitation period shall begin to run from that time [20]. In the case of a compound criminal offense, the statute of limitations begins to run from the moment when the last part is committee, namely the last action of that whole. For continuing criminal offenses, the statute of limitations begins to run from the moment when the last action is taken, which is part of the ongoing criminal offense. For permanent criminal offenses, the SoL periods shall run from the moment when the illegal situation has ceased. In collective criminal offenses, the statute of limitations begins to run from the day when the last offense was committed, which enters as part of a collective criminal offense [2, p. 556]. 
According to the article 100, paragraph 2 of the Criminal Code of the Republic the Kosovo it has been provided that in the case of an offense committed against a person under the age of eighteen (18), the limitation period shall commence to run on the day the victim reaches the age of eighteen (18) years [21].

Also, according to the professor Kambovski [14, p. 1069], the SoL of criminal offence forgery of documents (article 378, Criminal Code of Macedonia) starts from the day when the document has been used (so has the case law of Macedonia provided, GJSM, Ap, nr.35/2000. PVGJ, IX 40). The law on Liability of Legal Entities for Criminal Offenses, Article 14, paragraph 1, provides

Law on Liability of Legal Persons for Criminal Offences article 14, paragraph 1, provides that the statute of limitations for criminal prosecution of a legal person is calculated according to the sentence provided for the legal person who has committed the criminal offence [22].

The interruption of statute of limitations for criminal prosecution appears when, due to certain circumstances provided by law, prosecution cannot be initiated or if it has been started it cannot be continued according to law. During this time, as long as those circumstances are present, which prevent the initiation or continuation of criminal prosecution, the statute of limitations does not run.

In criminal law there are two types of obstacles that can cause the interruption of Sol: factual and legal obstacles.

The factual obstacles are those real circumstances and situations which makes it impossible to initiate or continue the criminal prosecution. In the Criminal Code of the Republic of Kosovo, article 100, paragraph 3 and sub-paragraph 1-4, is provided that the limitation period does not run for the time during which the prosecution cannot be started or continued according to law, including, but not limited to the following circumstances:

1. When the perpetrator is outside the Republic of Kosovo and this causes delays in the procedure;

2. When the perpetrator is required by an arrest warrant;

3. When waiting for an international legal request to obtain information or evidence before a foreign country or authority;

4. During the length of the guilty plea proceedings [23].

Circumstances or situations other than those provided by the Criminal Code there are also e.g. escape of the perpetrator; when the residence of the perpetrator is unknown; occupation of territory by the enemy; earthquake; floods; fire and other similar circumstances which make the work of the courts impossible [2, p. 557].

Legal Obstacles exists when it comes to any circumstance or situation of a legal nature, due to which such criminal prosecution cannot be initiated or continued e.g., are the immunity of the Member of Parliament, the mental illness of the defendant during the criminal proceedings, etc. In cases when the criminal offense was committed in cooperation, the interruption of the statute of limitations can be presented only to that associate in whom the circumstances exist or the above-mentioned situations, while for others the statute of limitations continues to run [24].

So, the first condition for the interruption of SoL is the undertaking of a procedural action by the authorized state bodies or the subjects included in this process, all this for the purpose of detecting and prosecuting the perpetrator. The subjects of the criminal procedure are authorized to undertake these actions: the court, the prosecutor and the authorized plaintiff. The second condition is that the action is taken in regard with a certain criminal offense and, finally, procedural actions should be taken against certain person/persons suspected of having committed a criminal offense. Article 100, paragraph 3 of the Criminal Code of the Republic of Kosovo clearly defines that the statute of limitations does not run for the time during which the prosecution cannot be started or continued according to law [25], and according to the same Code. Article 100, paragraph 7 provides that after each interruption of the statute of limitations, the new statute of limitations begins to run [26].

Criminal Code of the Republic of Kosovo under article 100, paragraph 3, recognizes two causes, which lead to the interruption of the SoL. First, the statute of limitations for criminal prosecution is interrupted by any action of the competent state body which is undertaken in order to prosecute the perpetrator for the committed criminal offense [25].

As well as Article 100, paragraph 6, the commission of a new criminal offense during the statute of limitations is the second reason that leads to the termination of the statute of limita- 
tions [27]. The new criminal offense in terms of gravity must be the same or more serious than the one committed before.

Tolling and interruption of SoL may indefinitely withdraw the submission of the statute of limitations and with it make this institute practically meaningless. The absolute statute of limitations for criminal prosecution is presented when twice the time required under paragraph 8 of Article 100 of the Criminal Code of the Republic of Kosovo has elapsed [28]. Thus, for example, for an offense it is provided that the statute of limitations is caused after 4 years, then the absolute statute of limitations is presented after the expiration of 8 years.

No statute of limitations applies to crimes of genocide, war crimes, crimes against humanity, or other criminal offenses which are not statute-barred under international law. The undisputed international basis of this decision is: United Nations Convention against the Prevention of War Crimes and Crimes against Humanity from 1968 as well as the European Convention on the Non-Applicability of SoL of Crimes against Humanity and War Crimes, adopted in 1974 [14, p. 1070]. Also, according to the Criminal Code of the Republic of Kosovo, no statutory limitation shall be applied to the criminal offense of aggravated murder [29] (paragraph 2, article 104).

\section{3. SoL of executions of punishments}

The statute of limitations for execution consists in the fact that after the expiration of the time provided by law, the sentence imposed cannot be executed. This situation occurs if the sentence has not started to be executed, or if its execution has been interrupted. [2, p. 558]. The statute of limitations for the execution of the sentence starts from the day when the judgment becomes final, and in case the alternative sentence is revoked, the statute of limitations starts from the day when the decision on revocation becomes final.

The statute of limitations for execution occurs for both main sentences and alternative and supplementary sentences.

The deadlines of statutory limitations for execution are different and they depend on the types and extent of the sentence imposed. Article 101 of the Criminal Code provides that, it unless otherwise provided by this Code, the sentence imposed may not be executed after the following periods have elapsed:

1. 1. thirty (30) years from a sentence of life long imprisonment;

1. 2. twenty (20) years from a sentence of imprisonment of more than ten (10) years;

1. 3. fifteen (15) years from a sentence of imprisonment of more than five (5) years;

1. 4. ten (10) years from a sentence of imprisonment of more than three (3) years;

1. 5. six (6) years from a sentence of imprisonment of more than one (1) year; and fine [30].

1. 6. four (4) years from a sentence of imprisonment up to one (1) year or punishment of a

So, according to this legal provision, the minimum statute of limitations for the execution of the sentence is four years, and the maximum is thirty years.

For additional sentences, the Criminal Code of the Republic of Kosovo provides special statute of limitations such as: prohibition of execution of other supplementary sentences when five (5) years have passed from the day the judgment with which the imposed sentence becomes final; Prohibition of the execution of the measure of compulsory treatment when three (3) years have passed from the day of the finality of the judgment with which the measure is imposed; as well as the statute of limitations for the execution of additional sentences and measures of compulsory treatment is terminated when the person does not comply with court orders regarding supplementary sentences and compulsory treatment measures [31].

The same as in the statute of limitations for criminal prosecution, also in the statute of limitations for the execution of the sentence, circumstances may arise, which cause the interruption and termination of the statute of limitations.

The statute of limitations for sentencing stops, does not run, during the time when according to the conditions provided by law, the execution of the sentence cannot be started. Circumstances due to which the sentence cannot be executed can be of legal and factual nature. Circumstances which lead to the termination of the statute of limitations are: for example, prolongation of the execution of the sentence according to the law on the execution of criminal sanctions. Also, prolongation of the execution of the sentence is possible when the convict becomes seriously ill, or a 
close family member dies. The sentence cannot be executed; therefore, the statute of limitations is stopped even in cases when the prosecuting authorities cannot find the convicted person [2, p. 552].

The statute of limitations is interrupted by any action initiated by the competent body in order to execute the sentence. As with the interruption of the statute of limitations for criminal prosecution, it is the same as with the interruption of the statute of limitations for the execution of the sentence, the time which run till the moment of interruption of the SoL is not counted. The Criminal Code has provided that after each interruption, a new statute of limitations begins to run.

The absolute SoL of the execution of the sentence [32] appears in any case when twice the time required by law for the statute of limitations for the execution of the sentence has elapsed, regardless of whether the tolling and interruption occurred and regardless of their duration (article 103, paragraph 6). In case the absolute statute of limitations for the execution of the sentence is caused, the imposed sentence can never be executed.

However, the paper did not encounter any restrictions because it did not deal with statistical data. Perhaps in the future other researchers will take a comparative approach with the SoL institute in Kosovo and the other countries of the region. The paper contributes to the existing legal literature, especially in the narrow criminal field, moreover, will reflect on the intention to undertake new research through which an assessment would be achieved on the effect of positive norms, namely the effect of the amendment of 2019 of the Criminal Code in relation to the institute of SoL.

\section{Conclusions}

The paper shows that the Republic of Kosovo with the amendments to the new provisions of the Criminal Code that entered into force on 14 January 2019, the statute of limitations period has been increased, especially in the statute of limitations for the execution of sentences with a maximum of thirty (30) years from life imprisonment to a minimum of four (4) years from imprisonment to one (1) year or a fine. With these amendments to the provisions of the Criminal Code, Kosovo gives a big blow to perpetrators, because in the past some of them have escaped prosecution as well as execution of the sentence. Today, the police, the prosecution and the court will have more time to prosecute the perpetrators of criminal offenses and their trial.

The paper results will help other researches in the identification of new ways to increase the efficiency of work in the prosecuting authorities but also in the judicial system in order to complete as many cases as possible to reduce the possibilities of SoL of criminal cases.

It is possible to say that at the world level, the statute of limitations is internationally recognized, many analyzes, researches and works related to SoL have been achieved. In the contrary, in Kosovo there is a small number of scientific studies published in international journals, relating to the institute of SoL, therefore the methods of detecting and preventing this phenomenon are deprived of the scientific basis. This knowledge presents an obvious problem that deserves adequate scientific elaboration in the future by lawyers as well as criminologists, sociologists but also by several NGOs in Kosovo.

\section{References}

[1] Brilmayer, L., Goldsmith, J., O’Hara O’Connor, E., Vázquez, C. (2019). Conflicts of Law (Cases and Law). Traditional Approaches to Choice of Law. Wolters Kluwer, 142.

[2] Salihu, I. (2012). E drejta Penale, pjesa e përgjithshme. Universiteti "Fama".

[3] Kodi Penal Përkohshëm i Republikës së Kosovës, i aprovuar me 6 korrik 2003, i cila ka hy në fuqi me 6 prill, 2004 (2003). UNMIK/Rreg/2003/25 Gazeta zyrtare 6 korrik 2003.

[4] Kodi Penal i Republikës së Kosovës, i aprovuar me 13.07.2012, i cila ka hy në fuqi me 1 janar 2013 (2012). Gazeta Zyrtare e Republikës së Kosovës, 19. Prishtinë.

[5] Kodi Penal i Republikës së Kosovës, i Shpallur me dekretin Nr. DL-065-2018, datë 13.12.2018 nga Presidenti i Republikës, dhe hyri në fuqi tre (3) muaj pas publikimit në Gazetën Zyrtare të Republikës së Kosovës (2019). Gazeta Zyrtare e Republikës së Kosovës, 2. Prishtinë.

[6] Salihu, I. (2011). E drejta Penale ndërkombëtare. Universiteti "Fama”, 496.

[7] Hajdari, A. (2010). E drejta e procedura penale. Prishtune.

[8] Hajdari, A. (2010). Komentar: Kodi i Procedures penale. Universiteti Fama. Prishtinë.

[9] Shala, A. (2011). E drejta Penale I. Kolegji Universitar “Gjilani”. Gjilan.

[10] Maloku, A. (2015). Fear of Violence and Criminality in the Region of Gjilan, Kosovo. Mediterranean Journal of Social Sciences, 6 (2 S5), 29-36. doi: http://doi.org/10.5901/mjss.2015.v6n2s5p29 
[11] Maloku, A. (2015). Bashkëpunimi ndërkombëtar policor në luftimin e krimit të organizuar. Regional Journal of Social Sciences Reforma, 2, 119-127.

[12] Krimet e përgjithshme në Kosovë, ligji vs praktika (2019). Kosovo Law Institute. Available at: https://kli-ks.org/krimet-epergjithshme-ne-kosove-ligji-vs-praktika/ Last accessed: 10.03.2021

[13] IKD: Shqetësuese dukuria e parashkrimit të lëndëve në Departamentet e Përgjithshme në Divizionin Penal (2019). Kosovo Law Institute. Available at: https://kli-ks.org/ikd-shqetesuese-dukuria-e-parashkrimit-te-lendeve-ne-departamentet-e-pergjithshme-ne-divizionin-penal/ Last accessed: 10.03.2021

[14] Kambovski, Vllado. E drejta penale, pjesa e përgjithshme, Universiteti “Shën Qirili dhe Metodi”, Shkup, 2006. p.1068.

[15] Kodi i Procedure Penale. Nr. 04/L-123 I (2012). Gazeta Zyrtare e Republikës së Kosovës, 37. Prishtinë. Neni 82, nen paragrafi 1.2.

[16] Kodi i Procedure Penale. Nr. 04/L-123 I (2012). Gazeta Zyrtare e Republikës së Kosovës, 37. Prishtinë. Neni 250, paragrafi 1 dhe nën paragrafi 1.3 .

[17] Kodi i Procedure Penale. Nr. 04/L-123 I (2012). Gazeta Zyrtare e Republikës së Kosovës, 37. Prishtinë. Neni 363, paragrafi 1 dhe nën paragrafi 1.3 .

[18] Kodi Penal i Republikës së Kosovës, i Shpallur me dekretin Nr. DL-065-2018, datë 13.12.2018 nga Presidenti i Republikës, dhe hyri në fuqi tre (3) muaj pas publikimit në Gazetën Zyrtare të Republikës së Kosovës (2019). Gazeta Zyrtare e Republikës së Kosovës, 2. Prishtinë. Neni 99, paragrafi 1.

[19] Kodi Penal i Republikës së Kosovës, i Shpallur me dekretin Nr. DL-065-2018, datë 13.12.2018 nga Presidenti i Republikës, dhe hyri në fuqi tre (3) muaj pas publikimit në Gazetën Zyrtare të Republikës së Kosovës (2019). Gazeta Zyrtare e Republikës së Kosovës, 2. Prishtinë. Neni 99, paragrafi 2.

[20] Kodi Penal i Republikës së Kosovës, i Shpallur me dekretin Nr. DL-065-2018, datë 13.12.2018 nga Presidenti i Republikës, dhe hyri në fuqi tre (3) muaj pas publikimit në Gazetën Zyrtare të Republikës së Kosovës (2019). Gazeta Zyrtare e Republikës së Kosovës, 2. Prishtinë. Neni 100, paragrafi 1.

[21] Kodi Penal i Republikës së Kosovës, i Shpallur me dekretin Nr. DL-065-2018, datë 13.12.2018 nga Presidenti i Republikës, dhe hyri në fuqi tre (3) muaj pas publikimit në Gazetën Zyrtare të Republikës së Kosovës (2019). Gazeta Zyrtare e Republikës së Kosovës, 2. Prishtinë. Neni 100, paragrafi 2.

[22] Ligj Nr. 04/L-030, për pergjegjësinë e personave juridik për vepra penale. i aprovuar me 31 gusht 2011, dhe ka hy në fuqi në fuqi më 1 janar 2013 (2011). Neni 14, paragrafi 1.

[23] Kodi Penal i Republikës së Kosovës, i Shpallur me dekretin Nr. DL-065-2018, datë 13.12.2018 nga Presidenti i Republikës, dhe hyri në fuqi tre (3) muaj pas publikimit në Gazetën Zyrtare të Republikës së Kosovës (2019). Gazeta Zyrtare e Republikës së Kosovës, 2. Prishtinë. Neni 100, paragrafi 3.

[24] Salihu, I. (2011). E drejta Penale ndërkombëtare. Universiteti "Fama", 561-562.

[25] Kodi Penal i Republikës së Kosovës, i Shpallur me dekretin Nr. DL-065-2018, datë 13.12.2018 nga Presidenti i Republikës, dhe hyri në fuqi tre (3) muaj pas publikimit në Gazetën Zyrtare të Republikës së Kosovës (2019). Gazeta Zyrtare e Republikës së Kosovës, 2. Prishtinë. Neni 100, paragrafi 3.

[26] Kodi Penal i Republikës së Kosovës, i Shpallur me dekretin Nr. DL-065-2018, datë 13.12.2018 nga Presidenti i Republikës, dhe hyri në fuqi tre (3) muaj pas publikimit në Gazetën Zyrtare të Republikës së Kosovës (2019). Gazeta Zyrtare e Republikës së Kosovës, 2. Prishtinë. Neni 100, paragrafi 7.

[27] Kodi Penal i Republikës së Kosovës, i Shpallur me dekretin Nr. DL-065-2018, datë 13.12.2018 nga Presidenti i Republikës, dhe hyri në fuqi tre (3) muaj pas publikimit në Gazetën Zyrtare të Republikës së Kosovës (2019). Gazeta Zyrtare e Republikës së Kosovës, 2. Prishtinë. Neni 100, paragrafi 6.

[28] Kodi Penal i Republikës së Kosovës, i Shpallur me dekretin Nr. DL-065-2018, datë 13.12.2018 nga Presidenti i Republikës, dhe hyri në fuqi tre (3) muaj pas publikimit në Gazetën Zyrtare të Republikës së Kosovës (2019). Gazeta Zyrtare e Republikës së Kosovës, 2. Prishtinë. Neni 100, paragrafit 8.

[29] Kodi Penal i Republikës së Kosovës, i Shpallur me dekretin Nr. DL-065-2018, datë 13.12.2018 nga Presidenti i Republikës, dhe hyri në fuqi tre (3) muaj pas publikimit në Gazetën Zyrtare të Republikës së Kosovës (2019). Gazeta Zyrtare e Republikës së Kosovës, 2. Prishtinë. Neni 100, paragrafit 8. Neni 104, paragrafi 2.

[30] Kodi Penal i Republikës së Kosovës, i Shpallur me dekretin Nr. DL-065-2018, datë 13.12.2018 nga Presidenti i Republikës, dhe hyri në fuqi tre (3) muaj pas publikimit në Gazetën Zyrtare të Republikës së Kosovës (2019). Gazeta Zyrtare e Republikës së Kosovës, 2. Prishtinë. Neni 101, paragrafi 1

[31] Kodi Penal i Republikës së Kosovës, i Shpallur me dekretin Nr. DL-065-2018, datë 13.12.2018 nga Presidenti i Republikës, dhe hyri në fuqi tre (3) muaj pas publikimit në Gazetën Zyrtare të Republikës së Kosovës (2019). Gazeta Zyrtare e Republikës së Kosovës, 2. Prishtinë. Neni 102, paragrafi 1, 2, dhe 3.

[32] Kodi Penal i Republikës së Kosovës, i Shpallur me dekretin Nr. DL-065-2018, datë 13.12.2018 nga Presidenti i Republikës, dhe hyri në fuqi tre (3) muaj pas publikimit në Gazetën Zyrtare të Republikës së Kosovës (2019). Gazeta Zyrtare e Republikës së Kosovës, 2. Prishtinë. Neni 103, paragrafi 6. 